\title{
SURVIVAL OF ENDOPHYTIC DIAZOTROPHIC BACTERIA IN SOIL UNDER DIFFERENT MOISTURE LEVELS
}

\author{
André L.M. Oliveira ${ }^{1}$; Erineudo L. Canuto² ${ }^{2}$ Edmilson E. Silva ${ }^{3}$, Veronica M. Reis ${ }^{4}$; José I. Baldani*
}

${ }^{1}$ Departamento de Bioquímica Médica, Instituto de Ciências Biomédicas, Universidade Federal do Rio de Janeiro, Rio de Janeiro, RJ, Brasil; ${ }^{2}$ Laboratório de Biologia Celular e Tecidual, Centro de Biociências e Biotecnologia, Universidade Estadual do Norte Fluminense Darcy Ribeiro, Rio de Janeiro, RJ, Brasil; ${ }^{3}$ Departamento de Ciências do Solo, Instituto de Agronomia, Universidade Federal Rural do Rio de Janeiro, Rio de Janeiro, RJ, Brasil; ${ }^{4}$ Laboratório de Ecofisiologia Aplicada, Embrapa Agrobiologia, Rio de Janeiro, RJ, Brasil

Submitted: December 01, 2003; Returned to authors for corrections: April 08, 2004; Approved: November 11, 2004

\section{SHORT COMMUNICATION}

\begin{abstract}
The effects of soil moisture on the survival of three diazotrophic bacteria species (Azospirillum amazonense, Gluconacetobacter diazotrophicus and Azospirillum brasilense) were tested. Soil moisture had little influence on the survival of $A$. brasilense, which is considered a free-living species. On the other hand, increased soil moisture extended the survival of the endophytes A. amazonense and $G$. diazotrophicus. These results indicate that nitrogen-fixing endophytic species are more affected by soil moisture than associative nitrogenfixing species.
\end{abstract}

Key words: Endophytic bacteria, soil survival, Gluconacetobacter diazotrophicus, Azospirillum amazonense, Azospirillum brasilense

Plant growth promoting (PGP) bacteria associated with sugarcane have been found to improve biomass production, through the increased availability of biologically fixed nitrogen, and other possible growth promoting effects $(3,8)$. The endophytic characteristic of some PGP bacterial species qualify them as potential targets for genetic engineering with the potential for yield improvement due to the colonization of plant tissue (2). In spite of the progress made in ecological studies of PGP bacteria using Azospirillum species, such as the identification of preferential habitat, plant-bacteria interactions, nitrogen fixation and plant hormone production (21), little information is available concerning the survival of PGP bacterial species in the absence of the host plant. For example, $A$. brasilense strain $\mathrm{Cd}$ in soil decreased rapidly during the initial 15 day period, and was undetectable 25 days after inoculation (5); however large populations are maintained in the soil in the presence of root exudates, even in the absence of the plant (7).

Sugarcane plants are known to support several endophytic associations with bacteria, including Azospirillum spp. and Gluconacetobacter diazotrophicus (9). One of the Azospirillum species associated with sugarcane is Azospirillum amazonense. This species has been identified as an endophyte supported by its frequent isolation from stems, leaves and roots (20). A. amazonense differs from other Azospirillum species due to the low $\mathrm{pH}$ required for optimum growth $(\mathrm{pH} 6.0)$, and high sensitivity to alkaline conditions. A. amazonense also utilizes sucrose, requires low $\mathrm{O}_{2}$ concentrations for biological nitrogen fixation, does not denitrify and exhibits little or no nitrification activity (13).

Gluconacetobacter diazotrophicus (11) is another PGP bacterium associated with sugarcane, and was isolated from

*Corresponding author. Mailing address: Embrapa Agrobiologia, Chefia Geral. BR 465 (Antiga Estrada Rio-São Paulo), Km 47, Seropédica, 23890-000, Rio de Janeiro, RJ, Brasil. Tel.: (+5521) 2682-1500. Fax: (+5521) 2682-1230. E-mail: ibaldani@cnpab.embrapa.br 
the rhizosphere, roots, rhizomes, stems, leaves and sugarcane crop residues. Populations up to $10^{7}$ cells per gram of plant tissue have been reported (20). Survival of G. diazotrophicus in the soil was shown to be very low, and structures such as cysts or capsules have not been observed. Attempts to isolate this organism from soil in the absence of a host plant have been unsuccessful (2). In spite of these observations, G. diazotrophicus has been isolated from spores of arbuscular fungi present in soil cultivated with sugarcane (16), from the digestive track of the meallybug Saccharococcus sacchari (3) and from internal tissues of 6-months-old micropropagated sugarcane grown in the field (19). Detection of G. diazotrophicus, using DNA amplification with species-specific primers in seeds, sugarcane crop residues or soil cultivated with sugarcane in the states of Rio de Janeiro and São Paulo has been unsuccessful (1).

The effects of many biotic and abiotic variables on bacterial survival in soil have already been studied (6). However, few studies have evaluated the survival of PGP bacterial species associated with sugarcane in tropical soils. Moisture content is known to be a limiting factor for the isolation of these species from sugarcane plants in Brazil (18). In the case of Azospirillum species, increases in calcium carbonate content (increased $\mathrm{pH}$ ) and sand content in the soil (increasing soil porosity/aeration) adversely affect survival of these species in the soil in the absence of a host plant. On the other hand, increases in organic matter contents and soil water retention capacity promote survival of Azospirillum (7).

The aim of this study was to determine the effect of soil moisture on the survival of the sugarcane-associated bacteria G. diazotrophicus and A. amazonense. Both of these organisms colonise internal tissues of sugarcane and are considered to be endophytes. The survival of these strains in soil with different moisture contents was compared to the survival of A. brasilense, a rhizospheric bacterial species.

The strains used were: A. amazonense strain BR 11115 (CBAmC), originally isolated from the stems of a commercial sugarcane variety, G. diazotrophicus strain BR 11281 (PAL5) isolated from the roots of the commercial sugarcane variety SP77-5181 and A. brasilense strain BR 11001 (Sp7), isolated from the rhizosphere of Digitaria decumbens. The Embrapa Agrobiologia Culture Collection provided these strains, which were grown to the exponential phase in Dyg's liquid medium (15), harvested and washed three times with sterile water by centrifugation $(2,000 \mathrm{~g}$ for 5 minutes). The washed cells were ressuspended in sterile distilled water to a density of $10^{9}$ cells per ml, using a Neubauer chamber. Aliquots of $0.1 \mathrm{ml}$ of each cell suspension were used to inoculate $10 \mathrm{~g}$ of soil in glass test tubes to a final concentration of $10^{7}$ cells/g soil. The test tubes were sealed and vigorously agitated in order to distribute the inoculum. The inoculation resulted in a moisture content of approximately $5 \%$ of the water retention capacity (WRC) for all treatments. The WRC was calculated by saturating $500 \mathrm{ml}$ of soil and letting it stand for 48 hours to drain. The water retained in the soil was designated as the WRC.

The soil used was the B horizon of an Ultisol and its characteristics were: $\mathrm{pH} 4.8$ in water; $19 \%$ sand, $14 \%$ silt and $67 \%$ loam; extractable ions by chemical analysis were Al: $0.4 \mathrm{~g} / \mathrm{kg}$, Ca: $1.1 \mathrm{~g} / \mathrm{kg}, \mathrm{Mg}: 1.6 \mathrm{~g} / \mathrm{kg}, \mathrm{P}: 0.14 \mathrm{~g} / \mathrm{kg}, \mathrm{K}: 2.4 \mathrm{~g} / \mathrm{kg}, \mathrm{Cu}: 0.1 \mathrm{~g} / \mathrm{kg}, \mathrm{Mn}:$ $1.4 \mathrm{~g} / \mathrm{kg}$, Fe: $5.6 \mathrm{~g} / \mathrm{kg}$ and $\mathrm{Zn}: 0.4 \mathrm{~g} / \mathrm{kg}$. The soil was dried, and sifted through $2 \mathrm{~mm}$ mesh in order to homogenise the particles. Glass test tubes of $30 \mathrm{ml}$ were filled with 10 grams of the soil, and closed with a rubber stopper. The tubes were sterilised three times by autoclaving with a 48 hour interval between each sterilisation. Three moisture levels were tested: 5\% (dry soil), 35 and $70 \%$ of the WRC. Moisture was adjusted with sterile distilled water after inoculation with the bacterial species. After adjustment of the moisture content, the inoculated soils were incubated at $30^{\circ} \mathrm{C}$ in the dark until sampling time. No additional water was used to replace evaporation losses, but the weight of the tubes at the end of the experiment indicated that the evaporation losses were approximately $2 \%$ of the initial WRC.

The Most Probable Number (MPN) technique was used (20) to quantify bacterial species at each sampling time. The sampling times were 1, 7, 20, 43 and 75 days after inoculation. A soil sample $(10 \mathrm{~g})$ was resuspended in $10 \%$ sterile saline solution $(90 \mathrm{ml})$, and shaken for one hour at 200 RPM (Lab-Line H628). Aliquots of this suspension were diluted in $10 \%$ sterile saline solution and inoculated in selective semi-solid medium. LGI-P medium was used for counting $G$. diazotrophicus, LGI medium was used for A. amazonense and NFb medium was used for A. brasilense (15). The identity of the species obtained in the MPN assay was confirmed by pellicle formation in semi-solid media and the characteristics of colonies formed on solid media for each species. The experimental units were the glass tubes with $10 \mathrm{~g}$ of sterilized soil, sampled in triplicate for each moisture level and for each sampling time. Regressions were made by Sigma Plot Scientific Graphing Software 5.0 software (Jandel, San Rafael, Calif.).

A reduction of cell number in the experimental units for all three species was observed just after the inoculation. Nevertheless, different patterns among the species could be observed in the reduction of the populations (Figs. 1 to 3 ). In general, increased moisture content promoted cell culturability. The results also showed that soil moisture level has little influence on the survival of $A$. brasilense strain BR 11001. In addition, linear reduction in populations at all moisture levels were observed using regression analyses. These results agree with previous observations of Bashan and Vazquez (7), working with $A$. brasilense strain $\mathrm{Cd}$ in two natural soils and in homologous artificial soils from Israel.

On the other hand, moisture level influenced survival of the A. amazonense. The detection of A. amazonense cells, measured based on the growth in culture medium, was possible up to 20 days after inoculation (Fig. 2). The population was relatively high $\left(10^{4}\right.$ cells/g soil) at the highest moisture levels at 21 days 

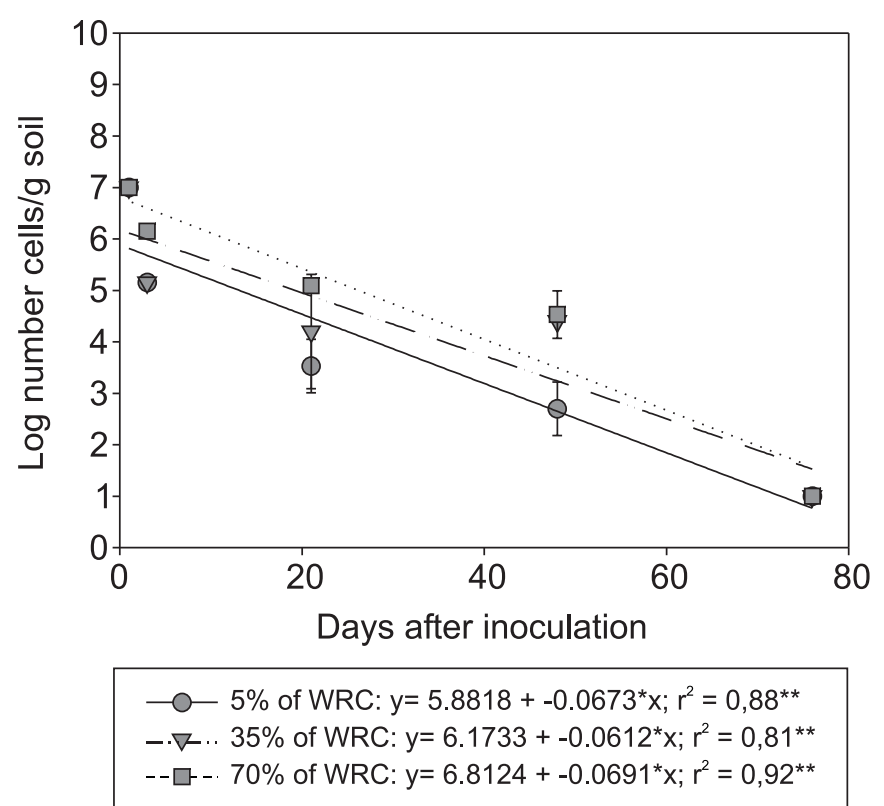

Figure 1. Survival of A. brasilense strain BR 11001 in sterilized soil under three moisture levels. $* * p<0.001$. Vertical bars denote standard error.

after inoculation. Low soil moisture adversely affected reisolation of $A$. amazonense at 48 hours after inoculation (Fig. 2 ). However, in contrast with $A$. brasilense, the reduction of the A. amazonense culturable population was exponential rather than linear. These results contrast with results obtained by Bashan and Vazquez (7) which showed that the reduction of $A$. amazonense strain 2787 population in natural and in artificial homologous soils from Israel with $10 \%$ (v/v) moisture was linear. Actually the loss of culturability of $A$. amazonense strain BR 11115 was linear if we consider the time period 20 days after soil inoculation (Fig. 2). Recently, Bashan and Vazquez (10) demonstrated that the culturability reduction of five Azospirillum species (including A. brasilense strain $\mathrm{Cd}$ and $A$. amazonense strain 2787) is rapid and follows a linear model. In addition, survival is affected by some of the variable soil components such as texture and carbonate levels. In this study, the non-linear reduction in cell number observed for $A$. amazonense strain BR 11115 in one soil type, with three different moisture levels, could be due to differences in strain characteristics or experimental procedure, the latter exhibiting a strong influence on the loss of culturability.

Survival of G. diazotrophicus was very similar to that of $A$. amazonense, and moisture content in the soil greatly influenced its survival. At the highest moisture content, G. diazotrophicus could be reisolated 40 days after inoculation from a population of $10^{3}$ cells/g of soil. Similar to A. amazonense, G. diazotrophicus could not be detected in dry soil 48 hours after inoculation. The

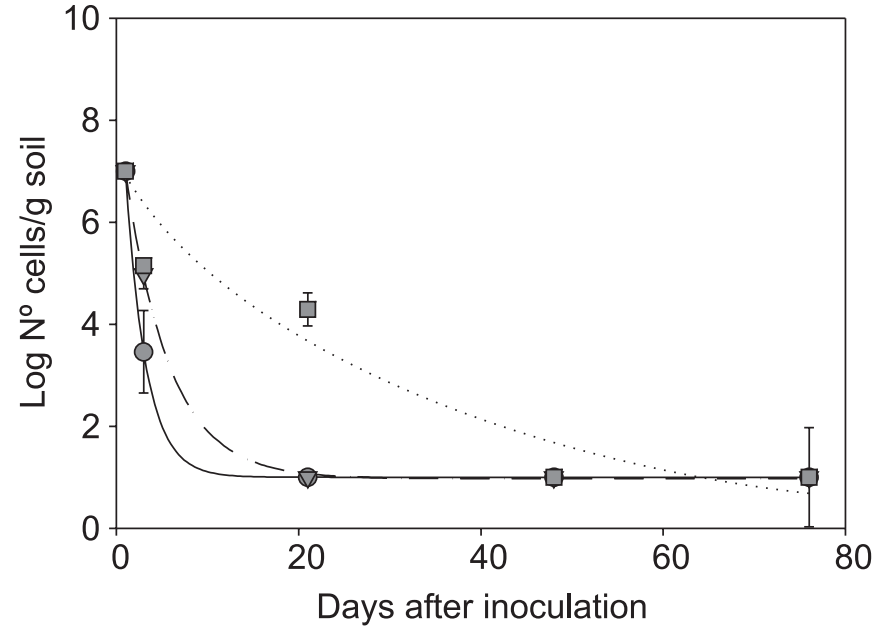

$-1-5 \%$ of WRC: $y=0.9997+9.3705^{*} \exp \left(-0.4458^{*} x\right) ; r^{2}=0.99^{* *}$
$-\nabla-35 \%$ of WRC: $y=0.9698+7.4270^{*} \exp \left(-0.2068^{*} x\right) ; r^{2}=0.99^{* *}$
$--\square-70 \%$ of WRC: $y=0.9997+9.3705^{*} \exp \left(-0.4458^{*} x\right) ; r^{2}=0.92^{* *}$

Figure 2. Survival of $A$. amazonense strain BR 11115 in sterilized soil under three moisture levels. $* * \mathrm{p}<0.001$. Vertical bars denote standard error.

reduction of $G$. diazotrophicus population also followed an exponential model (Fig. 3).

The persistence of PGP bacteria in the soil is crucial for the determination of the effects of inoculation, mode of infection and possible interactions of the inoculated species with the native soil biota. Among the PGP bacterial species associated with sugarcane, the Azospirillum genus is by far the most studied, including survival and persistence in the soil. In soil, the survival rate at $10 \%(\mathrm{v} / \mathrm{v})$ water content varies according to the species and soil characteristics (6). In tropical areas, this genus is very frequent, demonstrating a good capacity for survival and a widespread occurrence $(4,10)$. However, in temperate climate soils the survival of Azospirillum seems to be reduced $(6,22)$.

In general, as rhizosphere associated bacteria, Azospirillum species survive well and for long periods in association with several plant species (5). Among the mechanisms used by Azospirillum to overcome unfavorable conditions there are: cyst formation, flocculation, melanin production, synthesis of poly-ß-hidroxybutyrate (PHB), polysaccharide synthesis and association with micorrhizal fungi (5). Indeed, laboratory studies demonstrate the importance of the physiological state of the cells for their permanence in the soil after the inoculation (22). The effect of the soil moisture on the survival of the PGP bacterial species can be of either a physical or physiological nature. Soil moisture affects the motility of the bacteria, favouring the chemiotactic behaviour (5). Studies with soils from Israel and 


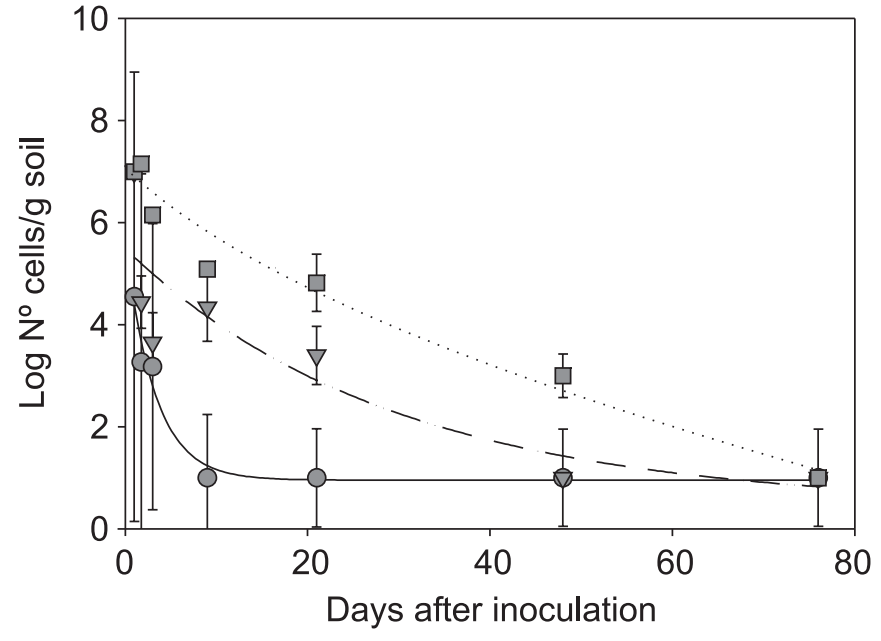

$-15 \%$ of WRC: $y=0.9538+4.7098^{*} \exp \left(-0.3114^{*} x\right) ; r^{2}=0.97^{* *}$

$-\nabla-.35 \%$ of WRC: $y=0.4479+5.0410^{*} \exp \left(-0.0341^{*} x\right) ; r^{2}=0,78^{* *}$

--ㅁ- - $70 \%$ of WRC: $y=-2.5449+9.3701^{*} \exp \left(-0.0122^{*} x\right) ; r^{2}=0,95^{* *}$

Figure 3. Survival of G. diazotrophicus strain BR 11281 in sterilized soil under three moisture levels. ${ }^{* *} \mathrm{p}<0.001$. Vertical bars denote standard error.

Mexico showed that clay content, nitrogen, organic matter and water retention capacity are positively correlated with the viability of A. brasilense strains Cd and Sp 245 (6). The degree of adsorption of the bacteria to soil particles is influenced by surface electrical charges, which in turn are affected by soil humidity and $\mathrm{pH}$. A decrease in soil humidity or an increase in soil $\mathrm{pH}$ reduce the adsorption of bacteria to soil particles (5). Most of the indigenous soil bacteria are permanently adsorbed to soil particles in a non-culturable form (17). Since PGP bacterial species survive poorly in soil, in the absence of a host plant, soil moisture allows the migration of the bacteria towards root exudates or more favourable niches.

In this work, the presence of moisture in the soil maintained the bacterial population at a level high enough to be detected 40 days after the inoculation, even for species considered as "obligate" endophytes such as G. diazotrophicus (2). In this study the failure to detect the bacterial species at low soil moisture might be related to the presence of cells in viable but not culturable state, as has been observed for Herbaspirillum and Ralstonia $(12,14)$. Several factors influence the survival of the PGP bacterial species in the soil and may be responsible for their persistence in the environment. The presence of cells in viable but non-culturable state, as well as the presence of resting forms such as cysts and spores or the association with mycorrhizal fungi are aspects that need to be explored to better understand the relationships between these organisms and the environment.

\section{ACKNOWLEDGEMENTS}

The authors thanks to CAPES, CNPq and PRONEX II for financial support.

\section{RESUMO}

\section{Sobrevivência de bactérias diazotróficas endofíticas no solo sob diferentes teores de umidade}

Neste trabalho foi avaliado o efeito da umidade do solo na sobrevivência de três espécies de bactérias diazotróficas (Azospirillum amazonense, Gluconacetobacter diazotrophicus e Azospirillum brasilense). O teor de umidade apresentou pouca influência na sobrevivência de $A$. brasilense, considerada uma espécie cosmopolita, enquanto A. amazonense e G. diazotrophicus, consideradas endofíticas, aumentaram o período de culturabilidade na presença de umidade no solo. Os resultados demonstram que o teor de umidade do solo possui maior influência nas espécies endofíticas, em comparação às espécies associativas.

Palavras-chave: bactérias endofíticas, sobrevivência no solo, Gluconacetobacter diazotrophicus, Azospirillum amazonense, Azospirillum brasilense

\section{REFERENCES}

1. Arcanjo S.S.; Teixeira, K.R.S.; Baldani, J.I. Uso da técnica de PCR na detecção de Gluconacetobacter diazotrophicus em amostras de solos de canaviais. FERTBIO 2000, Santa Maria, 2000, CD ROM.

2. Baldani, J.I.; Caruso, L.; Baldani, V.L.D.; Goi, S.R.; Döbereiner, J. Recent advances in BNF with non-legume plants. Soil. Biol. Biochem., 29:911-922, 1997.

3. Baldani, J.I.; Reis, V.M.; Baldani, V.L.D.; Döbereiner, J. A brief story of nitrogen fixation in sugarcane - reasons for success in Brazil. Funct. Plant. Biol., 29:417-423, 2002.

4. Baldani, V.L.D.; Alvarez, M.A. de B.; Baldani, J.I.; Döbereiner, J. Establishment of inoculated Azospirillum spp. in the rhizosphere and in roots of field growth wheat and sorghum. Plant. Soil., 90:3546, 1986.

5. Bashan Y. Interactions of Azospirillum in soils: a review. Biol. Fertil. Soils., 29:246-256, 1999.

6. Bashan, Y.; Puente, M.E.; Rodriguez-Mendoza, M.N.; Toledo, G.; Holguin, G.; Ferrera-Cerrato, R.; Pedrin, S. Survival of Azospirillum brasilense in the bulk soil and rhizosphere of 23 soil types. Appl. Environm. Microbiol., 61:1938-1945, 1995.

7. Bashan, Y.; Vazquez, P. Effect of calcium carbonate, sand, and organic matter levels on mortality of five species of Azospirillum in natural and artificial bulk soils. Biol. Fertil. Soils., 30:450-459, 2000.

8. Boddey, R.M. Biological Nitrogen Fixation in sugar cane: a Key to energetically viable biofuel production. CRC Crit. Rev. Plant Sci., 14:263-279, 1995.

9. Döbereiner, J. History and new perspective of diazotrophs in association with non-leguminous plants. Symbiosis., 13:1-13, 1992.

10. Döbereiner, J.; Marriel, I.E.; Nery, M. Ecological distribution of Spirillum lipoferum Beijerinck. Can. J. Microbiol., 22:1464-1473, 1976. 
11. Gillis, M.; Kersters, K.; Hoste, B.; Janssens, P.; Kropenstedt, M.P.; Stephan, J.; Teixeira, K.R.S.; Döbereiner, J.; Deley, J. Acetobacter diazotrophicus sp. nov., a nitrogen-fixing acetic acid bacterium associated with sugarcane. Int. J. Syst. Bacteriol., 39:361-364, 1989.

12. Grey, B.E.; Steck, T.R. The viable but nonculturable state of Ralstonia solanacearum may be involved in long-term survival and plant infection. Appl. Environm. Microbiol., 67:3866-3872, 2001.

13. Magalhães, F.M.; Baldani, J.I.; Souto, S.M.; Kuykendall, J.R.; Döbereiner, J. A new acid-tolerant Azospirillum species. An. Acad. Bras. Cienc., 55:417-430, 1983.

14. Olivares, F.L.; Baldani, V.L.D.; Reis, V.M.; Baldani, J.I.; Döbereiner, J. Occurrence of the endophytic diazotrophs Herbaspirillum spp. in roots, stems and leaves predominantly of Gramineae. Biol. Fertil. Soils., 21:197-200, 1996.

15. Oliveira, A.L.M.; Urquiaga, S.; Dobereiner, J.; Baldani, J.I. The effect of inoculating endophytic N2-fixing bacteria on micropropagated sugarcane plants. Plant Soil., 242:205-215, 2002.

16. Paula, M.A.; Urquiaga, S.; Siqueira, J.O.; Döbereiner, J. Synergistic effects of vesicular arbuscular mycorrhizal fungi and diazotrophic bacteria on nutrition and growth of sweet potato (Ipomoea batatas). Biol. Fertil. Soils., 14:61-66, 1992.
17. Reier Bakken, L. Culturable and nonculturable bacteria in soil. In: van Elsas J.D.; Trevors J.T.; Wellington E.M.H. (eds.). Modern Soil Microbiology., Marcel Dekker, New York, 1997, p.183-213.

18. Reis Jr., F.B.; Reis, V.M.; Urquiaga, S.; Döbereiner, J. Influence of nitrogen fertilisation on the population of diazotrophic bacteria Herbaspirillum spp. and Acetobacter diazotrophicus in sugarcane (Saccharum spp.). Plant Soil., 219:153-159, 2000.

19. Reis Jr., F.B.; Silva, L.G.; Reis, V.M.; Dobereiner, J. Ocorrência de bactérias diazotróficas em diferentes genótipos de cana-de-açúcar. Pesq. Agr. Bras., 35:985-994, 2000.

20. Reis, V.M.; Olivares, F.L.; Döbereiner, J. Improved methodology for isolation of Acetobacter diazotrophicus and confirmation of its endophytic habitat. World J. Microbiol. Biotechnol., 10:401-405, 1994.

21. Steenhoudt, O.; Vanderleyden, J. Azospirillum, a free-living nitrogenfixing bacterium closely associated with grasses: genetic, biochemical and ecological aspects. FEMS Microbiol. Rev., 24:487-506, 2000.

22. Vandenhove, H.; Merckx, R.; van Steenbergen, M.; Vlassak, K. Microcalorimetric characterization, physiological stages and survival ability of Azospirillum brasilense. Soil Biol. Biochem., 25:513-519, 1993. 